\title{
THE SIGNIFICANCE OF THE C-REACTIVE PROTEIN ESTIMATION IN STREPTOCOCCAL AND ALLIED DISEASE
}

\author{
BY \\ SHEILA F. DAWSON \\ From Booth Hall Children's Hospital, Manchester
}

(RECEIVED FOR PUbliCATION MAY 14, 1957)

C-reactive protein is a specific protein which was first reported by Tillett and Francis in 1930 to be present in the serum of patients suffering from pneumococcal pneumonia. It was precipitated by the addition of the somatic $\mathrm{C}$ polysaccharide of the pneumococcus to the serum of these patients while in the acute phase of the illness, but the reaction disappeared during convalescence.

Originally thought to be a specific antibody against the pneumococcus, C-reactive protein was later found to appear in human serum in response to a variety of inflammatory conditions and to tissue necrosis. It is absent from normal serum. Abernethy and Avery (1941) suggested that it was associated with the albumin fraction of the serum after salt fractionation, but Perlman, Bullowa and Goodkind (1943) showed by electrophoretic analysis that C-reactive protein is an alpha globulin.

In contrast $\mathrm{C}$ polysaccharide antibody is found in the globulin portion of the serum after salt fractionation and has the electrophoretic mobility of gamma globulin, and does not disappear when the active phase of an illness has passed (Löfström, 1944). C-reactive protein was isolated and purified by MacLeod and Avery (1941). By injecting the purified protein into rabbits a specific antiserum was obtained which gave no reaction with normal human serum.

The protein has been further purified by crystallization, and the Schieffelin Company, New York, has produced the specific antiserum for C-reactive protein on a commercial scale. The use of this antiserum makes the detection of C-reactive protein in the serum a simple test.

\section{Method}

The test is a qualitative and quantitative precipitin reaction for C-reactive protein in a patient's serum.

The test was carried out in capillary tubes $90 \mathrm{~mm}$. long and internal diameter $0.4 \mathrm{~mm}$. A column,
$3 \mathrm{~cm}$. long, of C-reactive protein antiserum was drawn into the capillary tube and then a column of equal length of the patient's serum was drawn into the same capillary, care being taken to avoid air bubbles between the two sera. The tubes were placed vertically in stands (with antiserum in the upper part of the tubes), incubated for two hours at $37^{\circ} \mathrm{C}$. and then left in the refrigerator for 22 hours.

Qualitative readings were obtained after two hours and expressed as positive or negative. Final readings were obtained after 24 hours and expressed quantitatively as the length of the column of precipitate in millimetres.

\section{Cases Investigated}

We were chiefly interested in the streptococcal diseases and those diseases probably allied to the streptococcal group.

One hundred and forty cases were studied and their distribution was as follows:

$\begin{array}{lllr}\text { Primary tonsillitis } & . & \ldots & 43 \text { cases } \\ \text { Rheumatic fever } & . & . . & 57 \text { cases } \\ \text { Rheumatic chorea } & \ldots & \ldots & 7 \text { cases } \\ \text { Nephritis } & . . & 15 \text { cases } \\ \text { Rheumatoid arthritis } & \ldots & 5 \text { cases } \\ \text { Schönlein Henoch purpura } & 9 \text { cases } \\ \text { Erythema nodosum } & . . & 4 \text { cases }\end{array}$

Multiple estimations were carried out in all cases, the tests being performed within 48 hours of admission to hospital and repeated at intervals of five to seven days.

Erythrocyte sedimentation rates (Westergren method) were estimated on blood samples taken simultaneously with those for the detection of C-reactive protein.

The sedimentation rates were expressed as millimetres in the first hour; below $10 \mathrm{~mm}$. was regarded as normal, above $20 \mathrm{~mm}$. as raised and from $10 \mathrm{~mm}$. to $20 \mathrm{~mm}$. as of doubtful significance.

\section{Results and their Interpretation in the Different Groups}

Primary Tonsillitis. In this group of 43 cases, two relapsed within a short interval of the initial infection. Haemolytic streptococci group A were 
isolated from the throat swabs in $40 \%$ of the patients. Two-thirds of the remaining $60 \%$ had had oral penicillin or sulphonamides before admission to hospital and this probably explains why haemolytic streptococci were not grown from their throat swabs.

Positive C-reactive protein tests were obtained on the first to eighth days after the onset of symptoms and not later than the eighth day except in the two patients who had a relapse shortly after the initial infection. In these two cases positive results were obtained on the tenth and twelfth days respectively from the onset of the initial attack. It was also noted that the earlier treatment was begun the sooner the C-reactive protein test became negative, and the level of the C-reactive protein was roughly proportional to the severity of the infection with levels of $5 \mathrm{~mm}$. in those patients who had an associated cervical adenitis. There was no significant difference in the results obtained in those patients from whom haemolytic streptococci group A had been isolated compared with those where the organism had not been found.

From the table it is not unreasonable to conclude that the C-reactive protein test correlates more closely with clinical activity than the E.S.R., which remained elevated for a few days after the $\mathrm{C}$-reactive protein test had become negative in several cases.

Rheumatic Fever. This group of 57 cases was

Twenty-Four Cases without Carditis. These included 14 cases where the patients attended with a history of limb pains following tonsillitis but had no objective signs of active rheumatism, five cases with no clinical activity on admission and five patients admitted with arthritis only, who never developed any signs of carditis.

Thirty-Three CaSes with Carditis. The carditis was graded as mild in 12 patients who had minimal clinical signs as expressed by pulse rate and temperature, and only a soft localized apical systolic murmur which disappeared completely before discharge. In a further 21 patients the carditis was judged to be further subdivided as follows:

of a moderate to severe degree, since they had marked cardiac involvement. All these patients had an apical systolic murmur propagated to the axilla and many had a diastolic murmur; they had residual fading murmurs or other definite evidence of cardiac damage on discharge.

The 12 patients whose carditis was graded as mild were all treated with salicylates, while of the 21 patients who had a carditis of moderate to severe degree 15 were treated with salicylates and the remaining six with prednisolone.

CASES WITHOUT CARDITIS. In this subgroup of 24 cases the $\mathrm{C}$-reactive protein test was negative unless the patients had an active arthritis at the time of or just before the test was done.

Of the 14 cases with limb pains only, nine were clinically inactive, with an E.S.R. under $10 \mathrm{~mm}$., and a negative $\mathrm{C}$-reactive protein test merely confirmed the inactivity. The other five patients had a sedimentation rate in the doubtful range which, together with a soft apical systolic murmur, made a decision difficult. The $\mathrm{C}$-reactive protein test was negative and reflected the clinical view that there was no rheumatic activity and that the murmurs were functional.

The C-reactive protein test was negative in the five cases not clinically active on admission. Two of these cases had a raised E.S.R. between 30 and $40 \mathrm{~mm}$. which settled to below $10 \mathrm{~mm}$. within two weeks of admission without any other signs of clinical activity developing in the period before the E.S.R. fell to normal limits.

The five cases with arthritis were the only ones in which the C-reactive protein test was positive and it remained positive for a few days after the arthritis had subsided, becoming negative on an average by the fifteenth day of the disease.

Cases with Carditis. The C-reactive protein test was initially positive in all 33 cases of this subgroup and the length of time the test remained positive was proportional to the severity of the carditis. In the 12 cases where the carditis was graded as mild and treated with salicylates, the average time before the test became negative was 25 days. The average

TABLE 1

COMPARISON OF CLINICAL CONDITION, C-REACTIVE PROTEIN AND E.S.R. IN TONSILLITIS

\begin{tabular}{|c|c|c|c|c|c|}
\hline \multirow[b]{2}{*}{ No. of Cases } & \multirow[b]{2}{*}{ Clinical State } & \multirow[b]{2}{*}{ C-reactive Protein } & \multicolumn{3}{|c|}{ E.S.R. } \\
\hline & & & Normal & Doubtful & Raised \\
\hline $\begin{array}{r}28 \\
3 \\
12\end{array}$ & $\begin{array}{l}\text { Active } \\
\text { Subsiding } \\
\text { Convalescent }\end{array}$ & $\begin{array}{l}\text { Positive, } 1 \text { to } 6 \mathrm{~mm} \text {, in all cases } \\
\text { Negative } 2 \text { cases. Positive } 1 \text { case, } 1 \mathrm{~mm} \text {. } \\
\text { Negative all cases }\end{array}$ & $\begin{array}{l}2 \\
6\end{array}$ & $\begin{array}{l}7 \\
2 \\
3\end{array}$ & $\begin{array}{r}19 \\
1 \\
3\end{array}$ \\
\hline
\end{tabular}

C.R.P. = C-reactive protein. 
time the test took to become negative from the onset of symptoms was longer in the patients whose carditis was graded from moderate to severe; it was 80 days in the 15 cases treated with salicylates but only 35 days in the six cases treated with prednisolone as shown in Fig. 1.

Correlation of Clinical Signs with C-reactive Protein in Rheumatic Fever. The C-reactive protein test remained positive after the patients became afebrile and the arthritis had subsided, and became negative about the time the tachycardia was settling and the murmurs started to fade.

The test gives a definite positive or negative result whereas the point where the pulse is settling and the murmurs disappearing is more easily seen from the records in retrospect than at the actual time.

Clinically in a few severe cases there was doubt as to the clinical activity for about a week after the C-reactive protein test had become negative. In those cases which relapsed the $\mathrm{C}$-reactive protein test became positive a few days before the relapse became clinically apparent.

Comparison of E.S.R. and C-reactive Protein in Rheumatic Fever. The E.S.R. followed the general trend of the C-reactive protein but appeared to lag behind in returning to normal as can be seen in Fig. 1 . This is further illustrated by the results in the five cases which were inactive on admission and had a negative C-reactive protein test, since in two of these cases the E.S.R. was raised at 30 to $40 \mathrm{~mm}$. and took two weeks to subside to within normal limits.

The E.S.R. also showed a delay in rising and therefore did not foreshadow the clinical recurrences as did the C-reactive protein. This delay occurred in all grades of carditis and Fig. 2 illustrates it in a case of mild carditis.

In one patient the E.S.R. was particularly misleading since it remained below $10 \mathrm{~mm}$. for the whole course of the disease, although there was undoubted clinical activity. The C-reactive protein gave a more accurate index of this activity (Fig. 3).

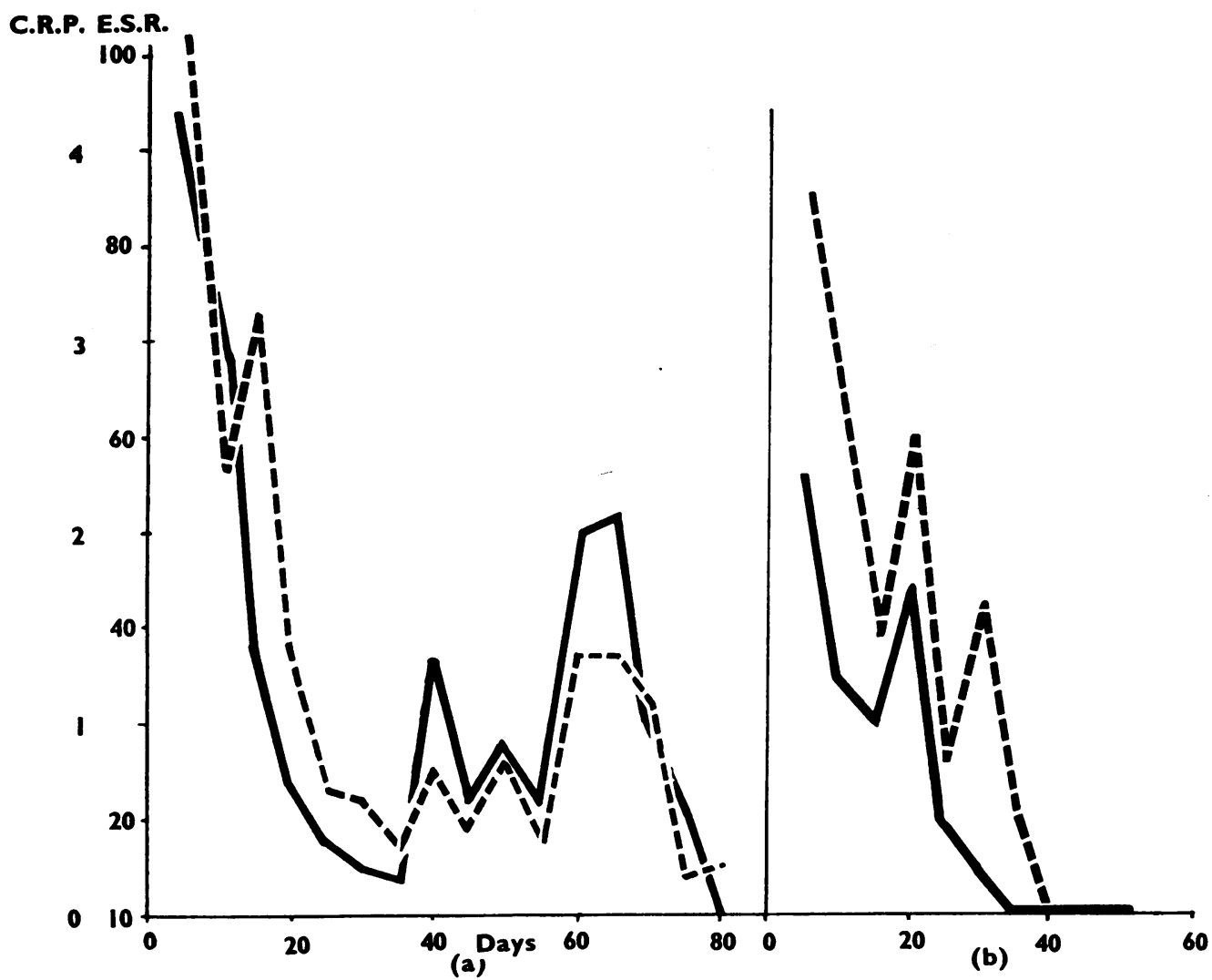

Fig. 1.-Comparison of the E.S.R. and C-reactive protein in moderate carditis. The graphs represent the mean of the 15 cases on salicylate (a) and the six on prednisolone (b). C.R.P. . - mm. of precipitate. E.S.R. - - - mm. Westergren. Note that $10 \mathrm{~mm}$. on the E.S.R. scale is placed level with the absence of a $\mathrm{C}$-reactive protein deposit. 


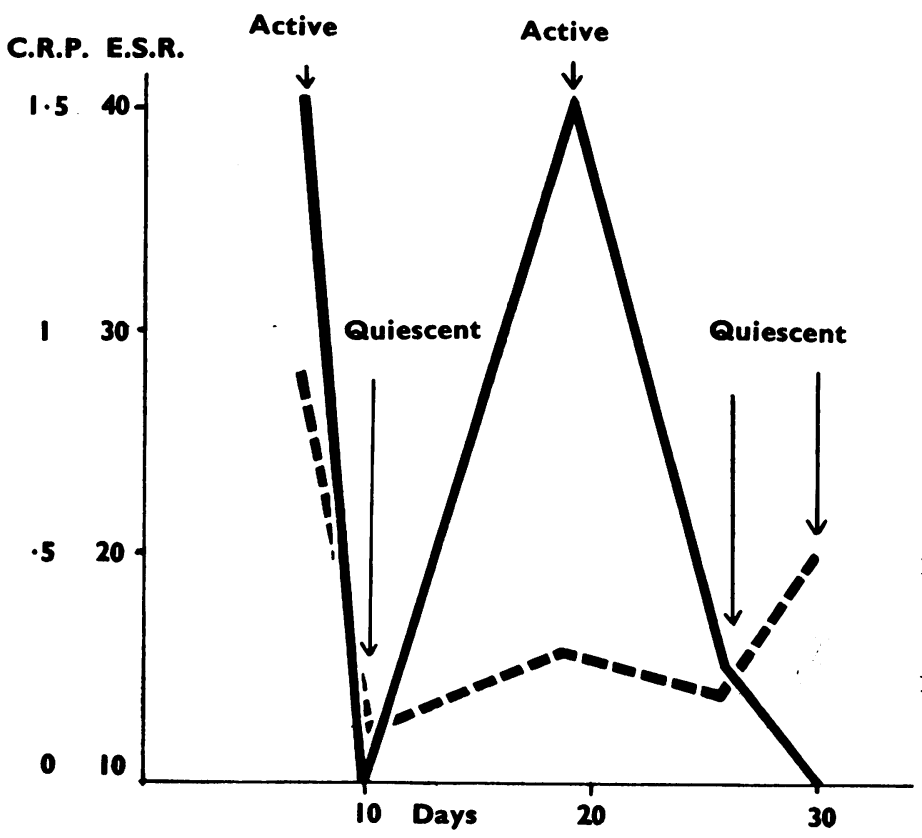

FIG. 2.- Lag of E.S.R. behind C-reactive protein in clinical recurrence of mild carditis (Case 22).

C.R.P. . mm. of precipitate.

E.S.R. - - - mm. Westergren.

Note that $10 \mathrm{~mm}$. on the E.S.R. scale is placed level with the absence of a C.R.P. deposit.

FIG. 3.-Normal E.S.R. and positive C-reactive protein in carditis and tonsillitis (Case 30).

C.R.P. .—. mm. of precipitate.

E.S.R. - - - - mm. Westergren.

Note that $10 \mathrm{~mm}$. on the E.S.R. scale is placed level with the absence of a C.R.P. deposit.

FIG. 2.

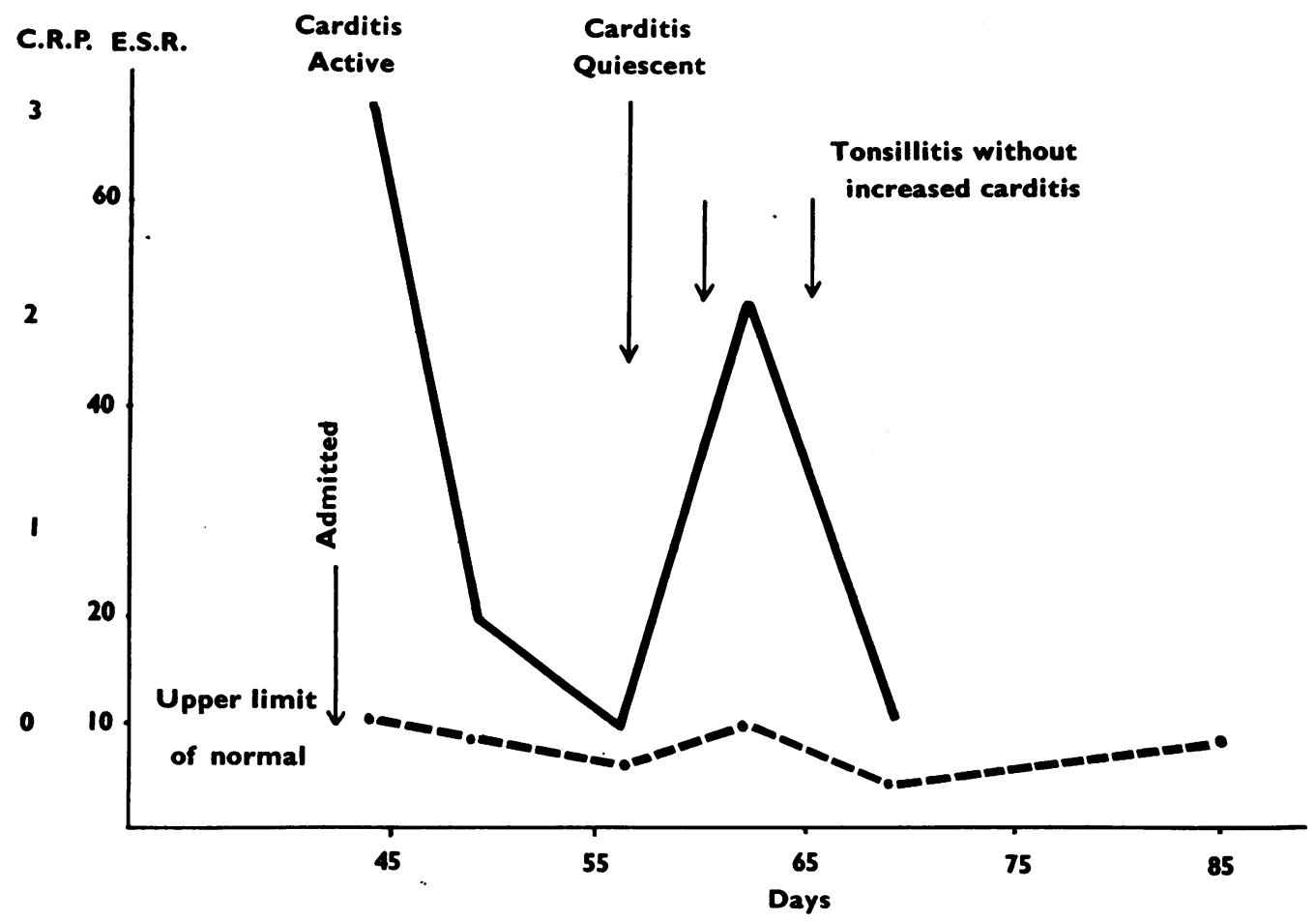

Fig. 3. 
Comparison of $\mathrm{C}$-reactive Protein in Tonsillitis and Rheumatic Fever. In primary tonsillitis, C-reactive protein was not present after the eighth day unless there was a recurrence of the tonsillitis. Fig. 4 shows the results of the $\mathrm{C}$-reactive protein test in the one case of tonsillitis which was followed by rheumatic fever contrasted with an uncomplicated case of tonsillitis. When the child was clinically well the C-reactive protein level actually rose before there was clinical evidence of carditis and persisted throughout the course of the carditis.

Six patients developed tonsillitis during the course of the rheumatic fever attack. In four, the tonsillitis was not complicated by any recurrence of carditis and the $C$-reactive protein test became negative between the sixth and the eighth day. In the remaining two patients the carditis recurred and the
C-reactive protein persisted until the condition subsided on the 24 th and 25 th day respectively after the onset of tonsillitis.

The results in these patients suggest that if the C-reactive protein test does not become negative within eight days, then a recurrence of the carditis should be anticipated.

Rheumatic Chorea. Seven children aged 6 to 14 years with active chorea but no carditis had E.S.R.s ranging from 8 to $18 \mathrm{~mm}$.; the C-reactive protein test was negative in all cases.

One case with mitral stenosis due to a previous carditis later developed a mild exacerbation (with rise in pulse rate, increase in cardiac murmurs and recurrent epistaxis) as the chorea was subsiding. The E.S.R. rose from 4 to $18 \mathrm{~mm}$. the C-reactive protein test became positive $(1.5 \mathrm{~mm}$.) and there was still a trace of the protein three weeks later when the sedimentation rate was $10 \mathrm{~mm}$. and the chorea had subsided.

Nephritis. There were 15 cases in this group. All gave a history of tonsillitis or upper respiratory tract infection one to five weeks before the onset of the nephritic symptoms. These infections had not been treated or the patients had received inadequate doses of oral penicillin or sulphonamides.

The common findings on examination of the urine were albuminuria, microscopic haematuria and granular casts. All the patients had a considerably raised sedimentation rate and the majority had hypertension and a raised blood urea level.

Seven of the 15 cases had a positive $\mathrm{C}$-reactive protein test on admission. Six of these seven cases were febrile and had active throat infections whereas only one of the eight cases in the negative $\mathrm{C}$-reactive protein 
group had clinical evidence of a throat infection. Otherwise there were no significant differences between the two groups in regard to clinical severity or time the E.S.R. took to return to normal values.

No positive C-reactive protein result was recorded after the eighth day, and negative results were recorded as early as the fourth day after the onset of nephritic symptoms. The sedimentation rate took an average of 25 days to settle below $20 \mathrm{~mm}$. The average time for the haematuria and albuminuria to decrease was 16 days and that for the urine to become normal on microscopy was $\mathbf{4 0}$ days.

The C-reactive protein is not as reliable a guide to the activity of nephritis as the E.S.R. seems to be.

The tissue reaction as judged by the presence of C-reactive protein differs in acute nephritis from that in rheumatic fever, because in the latter it persists throughout the active course of the disease.

Rheumatoid Arthritis. In all five cases the C-reactive protein remained elevated for long periods (up to two months in three cases). The rise in the C-reactive protein preceded the rise in the E.S.R. and the appearance of clinical joint manifestations and often became negative before the E.S.R. fell to normal.

Schönlein Henoch Purpura. There were nine patients in this group. The C-reactive protein test was negative in six cases and positive in the remaining three $(0.5$ to $2.5 \mathrm{~mm}$. on the second to ninth day of disease with E.S.R.s below $15 \mathrm{~mm}$.). The test became positive in one of two cases which relapsed. The cases with a positive result all had arthritis at the time of the test, whereas those with a negative test had purpuric manifestations only.

Two cases also had renal involvement; one had a persistently negative test although the E.S.R. became elevated with the onset of the nephritis (test taken on the second day of albuminuria and at weekly intervals thereafter); the other had arthritis and the positive test was more likely to have been associated with the arthritis than with the nephritis.

Erythema Nodosum. In only four of these cases could the rash be definitely related to a streptococcal infection and in these a positive $\mathrm{C}$-reactive protein test was recorded as late as the 20th day after the appearance of the rash. The E.S.R. again lagged behind the $\mathrm{C}$-reactive protein in returning to normal and remained raised even when there was no evidence of activity.

\section{Discussion}

Apart from two British papers by Hill (1951, 1952) all the investigations on C-reactive protein have been carried out in Scandinavia and America. Some of the literature was reviewed in editorials of the Lancet (1954) and the British Medical Journal (1956).

In this series the results in uncomplicated tonsillitis show quite clearly that the $\mathrm{C}$-reactive protein soon disappears from the serum. In treated cases a positive result was not obtained after the eighth day of disease. A persistently positive test should make one suspect the development of a complication of the streptococcal infection such as rheumatic fever. This was clearly shown in Case 20 (Fig. 4) where, although the tonsillitis subsided, C-reactive protein persisted in the latent interval before carditis was detected.

Anderson and McCarty (1950) found that in the majority of patients with streptococcal infection followed by rheumatic fever, C-reactive protein is present during the interval between the subsidence of the infection and the onset of carditis. Therefore they concluded that this latent interval is usually a period of subclinical rheumatism.

In the majority of results published on rheumatic fever a rough correlation has been noted between the C-reactive protein results and the E.S.R. During early convalescence it has been noted that there is a tendency for the sedimentation rate to remain raised after the $\mathrm{C}$-reactive protein has disappeared; similar results are reported in this series. In one patient Case 30 (Fig. 3) in this series of 57 cases of rheumatic fever, the combination of a normal E.S.R. with a positive C-reactive protein occurred. This occasional, but nevertheless very important discrepancy between the E.S.R. and the C-reactive protein has also been observed by Anderson and McCarty (1950). It points to the great value of the C-reactive protein as an index of rheumatic activity.

In our seven cases of chorea, six were uncomplicated by carditis and had negative C-reactive protein results. Anderson and McCarty (1950) and Stollerman, Glick, Patel, Hirschfeld and Rusoff (1953) likewise noted the absence of C-reactive protein in cases of uncomplicated Sydenham's chorea. The seventh case had a negative result until carditis developed as the chorea was subsiding, then the protein appeared in the serum and persisted throughout the carditis.

The five children with acute rheumatoid arthritis in this study all gave a positive C-reactive protein test, frequently for long periods, both in the presence of clinical activity and also in the absence of overt joint manifestation. Other studies of the C-reactive 
protein in rheumatoid arthritis have been in adults (the largest series by Hill, 1951), but since the clinical picture of acute rheumatoid arthritis in children differs from that in adults the results are not strictly comparable.

The reaction of the tissues in other diseases which may follow streptococcal infection has been mentioned only by Adams (1956). and seven cases of acute glomerulonephritis were included in his series of 'rheumatic fever, rheumatoid arthritis and streptococcosis'. Of the seven cases three had a positive and four a negative C-reactive protein test at the onset of the disease but no follow-up tests were carried out.

In the present series the results indicate that a positive C-reactive protein test in early glomerular nephritis is due to the associated streptococcal infection and not to the renal involvement, since the test became negative rapidly after the infection cleared.

In Schönlein Henoch purpura a positive C-reactive protein test was associated only with an acute arthritis. The uniformly positive results of the C-reactive protein test in active rheumatic carditis and the uniformly negative results in nephritis after the subsidence of the streptococcal infection are possibly due to a different tissue response.

\section{Summary}

The C-reactive protein was compared with the erythrocyte sedimentation rate and the clinical state in 140 cases of streptococcal and allied diseases.
The C-reactive protein estimation is an easy test to perform. Unlike the E.S.R. it is not influenced by other factors, such as anaemia or alterations in serum protein fractions, nor has it any range of doubtful values but gives a definite positive or negative result. Although it is a non-specific test which cannot be used for diagnosis, it has a definite value in assessing the degree of activity, particularly in rheumatic fever and rheumatoid arthritis. In these diseases there is closer correlation of the clinical activity with C-reactive protein than with the E.S.R. In acute nephritis it is of value only in assessing the persistence of streptococcal infection, but not in assessing the nephritic state.

I should like to thank Dr. A. Holzel and Dr. W. H. Patterson, under whose direction this study was carried out, for their advice and encouragement and Dr. L. Parker for his advice and the bacteriological investigations.

This study was made possible by a grant from the Hospital Endowment Fund and the Manchester Students Rag Committee.

Miss Perry very kindly prepared the diagrams.

REFERENCES

Abernethy, T. J. and Avery, O. T. (1941). J. exp. Med., 73, 173.

Adams, F. H. (1956). J. Pediat., 49, 16.

Anderson, H. C. and McCarty, M. (1950). Amer. J. Med., 8, 445. Editorial (1956). Brit. med. J., 2, 145.

- (1954). Lancet, 1, 350.

Hill, A. G. S. (1951). Ibid., 2, 807. (1952). Ibid., 2, 558.

Löfström, G. (1944). Brit. J. exp. Path., 25, 21.

MacLeod, C. M. and Avery, O. T. (1941). J. exp. Med., 73, 183.

Perlman, E., Bullowa, J. G. and Goodkind, R. (1943). Ibid., 77, 97. Stollerman, G. H., Glick, S., Patel, D. J., Hirschfeld, I. and Rusoff, J. H. (1953). Amer. J. Med., 15, 645.

Tillett, W. S. and Francis, T. Jr. (1930). J. exp. Med., 52, 561. 